\title{
SELF-PRESENTATION STRATEGIES APPLIED BY ACADEMIC TEACHERS AT UNIVERSITIES IN RZESZÓW AND THEIR POTENTIAL IMPACT ON STUDENTS: A CASE OF SELF-PROMOTION AND EXEMPLIFICATION
}

\begin{abstract}
The paper analyzes the application of self-presentation strategies in academic surroundings, and juxtaposes them with potential impact they may have on students. The data presented in the article constitute an excerpt of research on the application of five self-presentation strategies, i.e. ingratiation, intimidation, self-promotion, supplication, exemplification by academic teachers in Rzeszów, Poland, conducted in February and March 2018. Self-presentation, in simplified terms, constitutes the choice of behaviours to intentionally manage the impressions that others form of us, whereas a self-presentation strategy encompasses means of behaviour used to create a desirable image. The study encompasses 100 academic teachers, both men and women, between 26 and 62, employed at universities in Rzeszów. The research conducted by means of an online questionnaire indicated that self-promotion and exemplification were the least frequently applied choices. The rationale behind this result may be found in teacher's reluctance to appear as showing off or being vainglorious. Each of the strategies was covered by 5 questions thematically connected to them. While constructing the questions, it was attempted to adjust them thematically to the strategy in question as strongly as possible. Characteristic features of the two strategies were taken into account while shaping the cognitive reality around a question.
\end{abstract}

Keywords: self-presentation, strategy, self-promotion, exemplification, academic teacher.

\section{INTRODUCTION}

People strive for relatedness. They want to belong to groups of people they care about. Self-presentation is a predominant aspect of social existence, since our outcomes in life are underpinned by our success at making other people believe we have certain characteristics. People we are married to, our friends, colleagues, acquaintances, our performance at work or school, and many others are all contingent upon our abilities and skills to convince our audience that we are worthy of their appreciation, their feelings, their trust, and their respect.

\footnotetext{
${ }^{1}$ Magdalena Krawiec, MA, PhD student in the field of Linguistics, Institute of English Studies, Faculty of Philology, University of Rzeszów, e-mail: zboch.magdalena@gmail.com.

Magdalena Krawiec, doktorantka na kierunku językoznawstwo, Instytut Filologii Angielskiej, Uniwersytet Rzeszowski, e-mail: zboch.magdalena@gmail.com.
} 
Interestingly, people are most frequently audiences for their own behaviour, and while endeavouring to convince others that they have certain qualities, they usually also convince themselves. Essentially, people are aware that it is more probable to successfully integrate with those who perceive them positively. To this end, they frequently attempt to establish a favourable impression. Research methodology, aims and limits are described in the following sections.

\section{PURPOSES AND METHODOLOGY}

The data described in the article constitute an excerpt of research conducted in February and March 2018, pertinent to five self-presentation strategies, i.e. ingratiation, intimidation, self-promotion, supplication, exemplification, and their application by 100 academic teachers in Rzeszów, Poland.

The main aim of the research was to check which of the five strategies mentioned above were applied most frequently and what were the potential reasons for choosing these particular strategies - either voluntarily or involuntarily. Therefore the research is largely quantitative in nature. However, since the author also attempted to account for the impact that the said strategies may have on students and their performance, the paper may be deemed qualitative to some extent.

A self-report study based on an anonymous questionnaire - that requires no researcher's interference - was selected as the main method to gain participants' responses. Respondents' answers were located on a slightly modified Likert scale, in a way that respondents might have chosen from six, instead of five or seven answers and no midpoint was provided. The scale presents a symmetry and qualifiers are clearly defined linguistically. Consequently, equidistant attributes are more visible. The study was carried out by means of Google Forms - an online survey tool that enables questionnaire participants to show how strongly they agree or disagree with the statements.

A representative sample of 100 academic teachers, both men and women, between 26 and 62, employed at universities in Rzeszów completed the questionnaire. Each of the strategies covers 5 questions related thematically. While constructing the questions, it was attempted to adjust them thematically to the strategy in question as strongly as possible. Characteristic features of the two strategies (See Table 1) were taken into account while shaping the cognitive reality around a question.

The questions referring to the strategy of self-promotion are:

1. You are discussing something with one of your students. Suddenly you realize that you are not right. Have you ever defended your standpoint, although you knew you were wrong?

2. Have you ever talked to your students about your accomplishments? (e.g. your publications, conferences you participated in... etc.)

3. Have you ever ended a discussion just because you knew you were wrong?

4. Have you ever talked to your students about situations, when you were the one who was right, and the other person was completely wrong?

5. Have you ever deliberately used nomenclature that the students could hardly understand? 
The questions referring to the strategy of exemplification are:

1. Have you ever told your students that it is inappropriate to say or do something?

2. Have you ever deliberately made your students feel guilty?

3. Have you ever told your students that presently people lack morals?

4. Have you ever told your students that you would not finish the classes earlier, because it is against the rules?

5. Have you ever told your students that you find it difficult to understand modern youth?

The possible answers were "no, definitely not", "no", "rarely (almost never)", "yes, definitely", "yes, quite frequently", and "yes".

As regards the limits of the research, those are three-dimensional. Firstly, due to its quantitative nature the replies are not in-depth and all-embracing. Secondly, while the Likert scale is applied, respondents may tend to choose answers close to the middle of the scale, perhaps to look less extreme. Also there is a risk that e.g. "yes, definitely", and "yes" may mean different things to different people. Additionally, it is hard to assess whether the symmetry between "no" and "rarely (almost never)" is of the same kind or "length' as the one between "yes, definitely" and "yes, quite frequently". Thirdly, there is a risk that a participant gives an answer that they feel should be given in a given context.

\section{THE NOTION OF SELF-PRESENTATION}

In most simplified terms, self-presentation otherwise referred to as impression management, constitutes or, more precisely, reflects the image of our own selves, i.e. the image that we are willing to present. The term, though ubiquitous in common parlance, is neither straightforward, nor unequivocally accounted for.

Self-presentation is a fundamental sign of human social existence that is predicated upon an attempt to communicate who we are or how we want to be perceived, and expressed by dint of our words, non-verbal behaviour, and actions. If the objective of the said actions is to arrive at particular perception of our own selves, one may use the notion of impression management, i.e. 'the process by which individuals attempt to control the impressions others form of them. Because the impressions people make on others have implications for how others perceive, evaluate, and treat them, as well as for their own views of themselves, people sometimes behave in ways that will create certain impressions in others' eyes' ${ }^{2}$.

Despite the common view that impression management and self-presentation constitute equivalent terms, there are researchers, e.g. Schlenker ${ }^{3}$ postulating a distinction between them. He averred that impression management constitutes an endeavour to control images that one projects either in imagined or projected social interactions, whereas in the case of self-presentation - self-relevant ones. Simultaneously, since impressions may well be governed or managed not only by self-presentation but e.g. other entities such as PR agencies ${ }^{4}$,

\footnotetext{
${ }^{2}$ M.R. Leary, R.M. Kowalski, Impression management: A literature review and two-component model, "Psychological Bulletin", Washington 1990, p. 34.

${ }^{3}$ B.R. Schlenker, Impression management: The self-concept, social identity, and interpersonal relationships, Monterey, CA: Brooks/Cole, 1980.

${ }^{4}$ D.J. Schneider, Tactical self-presentations: Toward a broader conception [in:] Impression management theory and social psychological research, ed. J.T. Tedeschi, New York 1981.
} 
and conversely individuals may manage the impressions of entities other than themselves ${ }^{5}$, impression management encompasses more than self-presentation.

Also economists such as e.g. Akerlof and Kranton ${ }^{6,7}$, Bénabou and Tirole ${ }^{8,9}$ have scrutinized the role of self-image considerations as regards explaining behaviour. For Bursztyn and Jensen ${ }^{10}$, 'fully identifying and isolating self-image concerns is particularly challenging: we need to analyze behavior in which we are certain that the private cost of expression exceeds any anticipated consequential or social benefits. [...] Many actions that one might undertake are observable by others and may a send a signal about one's type. The type can be any attribute that a person may care about, whether economic, social, political or religious, just to name a few examples.'

To recapitulate, the approach adapted in this paper concurs in the recognition presented by Mark R. Leary and Robin M. Kowalski ${ }^{11}$ that impression management should only be viewed as fostering impressions in others' eyes. The author of this paper, as a linguist, also supports Leary's perspective that the notion should not be considered only in semantic terms, since there are certain conceptual constraints that preclude perceiving private selfimages and public impressions as equivalent terms. Both the terms are appropriate simultaneously only while elaborating on the way individuals control the impressions other people form of them, and only then can be applied interchangeably.

\section{SELF-PRESENTATION STRATEGIES}

As averred by Schlenker ${ }^{12}$, researchers emphasize that there is an interplay between social and individual levels in self-presentation, i.e. individual goals affect the social ones. People strive for relatedness, i.e. they want to belong to groups of people that they care for. Essentially, people are aware that it is more probable to successfully integrate with those who perceive them positively. To this end, people frequently try to establish a favourable impression. Notwithstanding, individual goals may sometimes be conducive to self-presenting in socially infelicitous ways ${ }^{13}$. People may self-deprecate so that others' expectations are lowered, or endeavour to seem intimidating to trigger fear.

${ }^{5}$ M.R. Leary, R.M. Kowalski, Impression management: A literature review and two-component model, "Psychological Bulletin", Washington 1990, p. 34.

${ }^{6}$ G.A Akerlof, R.E. Kranton, Economics and Identity, "The Quarterly Journal of Economics", Vol. 115/3, Oxford 2000, p. 715-753.

7 G.A. Akerlof, R.E. Kranton, Identity Economics: How Our Identities Shape Our Work, Wages, and Well-Being, Princeton University Press 2010.

8 R. Bénabou, J. Tirole, Intrinsic and Extrinsic Motivation, " The Review of Economic Studies", Vol. 70/3, London 2003, p. 489-520.

9 R. Bénabou, J. Tirole, Incentives and Prosocial Behavior, "American Economic Review", Vol. 96/5, American Economic Association 2006, p. 1652-1678.

${ }^{10}$ L. Bursztyn, R. Jensen, Social Image and Economic Behavior in the Field: Identifying, Understanding, and Shaping Social Pressure, "Annual Review of Economics", Vol. 9/1, Palo Alto, USA, 2017, p. 131-153.

11 Ibidem.

12 B.R. Schlenker, Self-presentation [in:] Handbook of Self and Identity, eds. M.R. Leary and J.P. Tangney, New York 2003, p. 492-518.

${ }^{13}$ Ibidem. 
Quite the other way round, the social level may also influence the individual one, since one's audience determines individual self-presentational goals. For instance, people incline towards being more self-aggrandizing as they encounter strangers and modest as they socialize with friends ${ }^{14}$. Psychological studies revealed that individual's private self-concept may be influenced by person's self-presentation to other people, which constitutes a conspicuous evidence that social level influences the individual one ${ }^{15}$. Certainly, for a selfconcept to change, one's actions need to be observed by others ${ }^{16}$, which underlines the social component.

The main purpose of self-presentation is to establish certain image in the minds of others. Though the count of resultant impressions may seem close to limitless, Jones and Pittmann ${ }^{17}$ arrived at a five-partite taxonomy of self-presentational strategies. For the sake of simplicity and conciseness, the said strategies are tabulated below, along with impressions they aim to trigger, prototypic behaviours, and risks.

Table 1. The concept of a five-partite representation of self-presentation strategies

\begin{tabular}{|l|l|l|l|}
\hline $\begin{array}{c}\text { Self-presentation } \\
\text { strategy }\end{array}$ & \multicolumn{1}{|c|}{ Impression } & Prototypic behaviours & \multicolumn{1}{|c|}{$\begin{array}{c}\text { Self-presentational } \\
\text { risks }\end{array}$} \\
\hline Ingratiation & Likable & Compliments, favours & Insincere, deceitful \\
\hline Self-promotion & Competent & Boasting, showing off & Conceited, fraudulent \\
\hline Intimidation & Powerful, ruthless & Threats, blackmail & Reviled, ineffectual \\
\hline Exemplification & $\begin{array}{l}\text { Virtuous, moral, } \\
\text { upright }\end{array}$ & Selflessness & $\begin{array}{l}\text { Hypocritical, } \\
\text { sanctimonious }\end{array}$ \\
\hline Supplication & Helpless, unable & Self-deprecation & Manipulative, demanding \\
\hline
\end{tabular}

Source: Author's own elaboration.

In further elaboration it is instructive to adduce Baumeister's wording: 'People use self-presentation to construct an identity for themselves. Most people have a certain ideal image of the person they would like to be. It is not enough merely to act like that person or to convince oneself that one resembles that person. Identity requires social validation' ${ }^{18}$.

${ }^{14}$ D.M. Tice, J.L. Butler, M.B. Muraven, A.M Stillwell, When modesty prevails: differential favorability of self-presentation to friends and strangers, "Journal of Personality and Social Psychology", Washington 1995, p. 1120-1138.

15 B.R. Schlenker, Self-presentation [in:] Handbook of Self and Identity, eds. M.R. Leary and J.P. Tangney, New York 2003, p. 492-518.

${ }^{16}$ D.M. Tice, H.M. Wallace, The reflected self: creating yourself as (you think) others see you [in:] Handbook of Self and Identity, eds. M.R. Leary and J.P. Tangney, New York 2003.

${ }^{17}$ E.E. Jones, T.S. Pittman, Toward a general theory of strategic self-presentation [in:] Psychological perspectives on the self, ed. J. Suls, New York 1982.

18 R.F. Baumeister, The self [in:] The Handbook of Social Psychology, eds. D.T. Gilbert, S.T. Fiske, G. Lindzey, New York 1998, p. 705. 


\section{ANALYSIS AND DISCUSSION}

\subsection{The strategy of self-promotion}

The strategy entitled self-promotion occurs while people are trying to draw attention to their attainments in order to be regarded as competent or capable. Though seemingly akin to ingratiation, the strategy of self-promotion does not focus on building a likable image. The first part of the research encompassed 5 questions connected to this strategy.

Question 1 You are discussing something with one of your students. Suddenly you realize that you are not right. Have you ever defended your standpoint, although you knew you were wrong?

Table 2. Distribution of answers to Question 1

\begin{tabular}{|l|c|c|}
\hline \multicolumn{1}{|c|}{ Answer } & Number of respondents & Percentage \\
\hline No, definitely not & 28 & $28 \%$ \\
\hline No & 53 & $53 \%$ \\
\hline Rarely (almost never) & 15 & $15 \%$ \\
\hline Yes & 4 & $4 \%$ \\
\hline Yes, quite frequently & 0 & $0 \%$ \\
\hline Yes, definitely & 0 & $0 \%$ \\
\hline
\end{tabular}

Source: Author's own elaboration based on research results.

As tabulated, the respondents were rather reluctant to carry on persuading their student interlocutor(s) that they were right in their judgment. In consonance with that, $28 \%$ and $53 \%$ of the respondents claimed that they did not defend their vantage point on purpose despite being wrong. Merely $4 \%$ of the academic teachers decided to have proceeded with the conversation, and $15 \%$ claimed to have done it rather infrequently. Such a distribution of answers may be contingent upon a fact that teachers, while self-promoting, want to appear as intelligent and proficient in their dedicated specialist area(s), yet not at the expense of being liked. Moreover, defending one's vantage point despite being obviously wrong, may make the teacher look conceited or fraudulent, which constitutes one of basic risks of self-promoting.

The seemingly trifling case of being liked or disliked also conditions students' performance during classes. When students like the teacher and attend the course willingly, their work and productivity improves ${ }^{19}$. As formulated by Montalvo and Roedel, 'students who dislike the teacher, but try to please the teacher anyway do the same things as students who like the teacher, but the difference seems to be in the amount of effort they put forth, and the quality of their work. Some students indicated that if they did not like the teacher they would turn their work in on time, but it may not be correct. On the other hand, when the students like a teacher and want to please them, they put extra effort into their assignments, have a positive attitude, and try to be more friendly with teachers ${ }^{20}$. That said, academic

${ }^{19}$ G.P. Montalvo, Pleasing the teacher: A student perspective, Unpublished manuscript, 1995.

${ }^{20}$ G.P. Montalvo, T. Roedel, Pleasing the teacher: A qualitative look, Paper presented at the annual meeting of the American Educational Research Association, San Francisco 1995. 
teachers eschew the strategy of self-promotion, inclining simultaneously towards the strategy of ingratiation, for they prefer to be likable.

Question 2 Have you ever talked to your students about your accomplishments? (e.g. your publications, conferences you participated in... etc.)

Table 3. Distribution of answers to Question 2

\begin{tabular}{|l|c|c|}
\hline \multicolumn{1}{|c|}{ Answer } & Number of respondents & Percentage \\
\hline No, definitely not & 0 & $0 \%$ \\
\hline No & 28 & $28 \%$ \\
\hline Rarely (almost never) & 49 & $49 \%$ \\
\hline Yes & 23 & $23 \%$ \\
\hline Yes, quite frequently & 0 & $0 \%$ \\
\hline Yes, definitely & 0 & $0 \%$ \\
\hline
\end{tabular}

Source: Author's own elaboration based on research results.

As plotted in the table, $23 \%$ of the respondents admitted sharing their achievements with their students, whereas almost half of the respondents were rather reluctant to talk about what they accomplished. Interestingly enough, none of the academic teachers gave an answer that was a definite 'no' or a definite 'yes'. The rationale behind this distribution of answers may be underpinned by teachers' fear of being perceived as boastful, conceited or even vainglorious.

Schlenker and Leary ${ }^{21}$ scrutinized the congruence between people's proclamations and performance. Conspicuously, the audience's judgment of competence is predicated upon (if available) performance information. Contrarily, if performance data are unavailable, the judgment is underlain by self-presentational claims of capabilities.

Interestingly, if the self-presentational information is not contradictory, the claims are taken at face value, i.e. if one claims to be competent, the audience assumes this is true. What may be inferred from a strictly self-presentational vantage point is that unless students know that the teacher is purposefully bending the truth, they are likely to give them the socalled benefit of the doubt, and believe their claims. Therefore, reasonably presenting yourself as competent is advantageous.

Question 3 Have you ever ended a discussion just because you knew you were wrong?

Table 4. Distribution of answers to Question 3

\begin{tabular}{|l|c|c|}
\hline \multicolumn{1}{|c|}{ Answer } & Number of respondents & Percentage \\
\hline No, definitely not & 22 & $22 \%$ \\
\hline No & 36 & $36 \%$ \\
\hline Rarely (almost never) & 33 & $33 \%$ \\
\hline Yes & 9 & $9 \%$ \\
\hline Yes, quite frequently & 0 & $0 \%$ \\
\hline Yes, definitely & 0 & $0 \%$ \\
\hline
\end{tabular}

Source: Author's own elaboration based on research results.

${ }^{21}$ B.R. Schlenker, M.R. Leary, Audiences' reactions to self-enhancing, self-denigrating, and accurate self-presentations, "Journal of Experimental Social Psychology", Washington 1982. 
As plotted in the table, $9 \%$ of the respondents explicitly admitted ending a discussion after finding out they were wrong. $33 \%$ of the survey participants did it infrequently, whereas the number of academic teachers who never did that totalled 58\%. Admittedly, ending a discussion in that way may result in students no longer perceiving the teacher as an expert. Again, with the strategy of self-promotion, it is attempted to convince others of our competence and capabilities. Notwithstanding, no matter which impressions people endeavour to build, they will come to fruition only if others approve of them.

Schlenker ${ }^{22}$ advanced a theory that successful self-presentation is predicated upon two assertions, i.e. beneficiality and believability. The first is pertinent to showing the most advantageous image possible, and the latter to making sure the image you present is believable. Admitting personal limits, faults, and mistakes builds trust and assists students in developing a perception that everybody makes mistakes and being an academic (or any other) teacher does not mean that one is always right and never errs. Furthermore, students' engagement is built through being accountable to them, ergo it is expedient to own one's mistakes. If an academic teacher ends a discussion without providing a good reason, they risk triggering suspicion and inadvertently building a bad impression.

Another important factor in establishing a desirable impression is accountability, which governs the aforementioned believability of a self-presentational claim. Ending a discussion enables the audience - here, the students - to immediately assess the veracity of teacher's proclamations.

Question 4 Have you ever talked to your students about situations, when you were the one who was right, and the other person was completely wrong?

Table 5. Distribution of answers to Question 4

\begin{tabular}{|l|c|c|}
\hline \multicolumn{1}{|c|}{ Answer } & Number of respondents & Percentage \\
\hline No, definitely not & 27 & $27 \%$ \\
\hline No & 39 & $39 \%$ \\
\hline Rarely (almost never) & 28 & $28 \%$ \\
\hline Yes & 6 & $6 \%$ \\
\hline Yes, quite frequently & 0 & $0 \%$ \\
\hline Yes, definitely & 0 & $0 \%$ \\
\hline
\end{tabular}

Source: Author's own elaboration based on research results.

Interestingly enough, merely $6 \%$ of the academic teachers stated explicitly that they were right while someone else was wrong. $28 \%$ of the respondents were tentative saying to have done it rather infrequently, whereas a total of $66 \%$ did not tell their students about such situations.

A case when someone illustrates their own behaviour against the backdrop of someone else's actions, providing simultaneously a sharp and subjective contrast between what is appropriate and what is not, is indicative of striving to appear as an expert. Essentially,

${ }^{22}$ B.R. Schlenker, Impression management: The self-concept, social identity, and interpersonal relationships, Monterey, CA: Brooks/Cole 1980. 
people are accountable when their proclamations and actions can be set against relevant facts. Schlenker ${ }^{23}$ studied self-presentation and accountability and the research revealed that people are reluctant to present themselves as competent only when they expect to fail and presume the audience can find out they were wrong. In this case, much as students were unlikely to examine teacher's credibility, the participants were not inclined to present themselves as superior by means of this method.

Question 5 Have you ever deliberately used nomenclature that the students could hardly understand?

Table 6. Distribution of answers to Question 5

\begin{tabular}{|l|c|c|}
\hline \multicolumn{1}{|c|}{ Answer } & Number of respondents & Percentage \\
\hline No, definitely not & 30 & $30 \%$ \\
\hline No & 27 & $27 \%$ \\
\hline Rarely (almost never) & 34 & $34 \%$ \\
\hline Yes & 9 & $9 \%$ \\
\hline Yes, quite frequently & 0 & $0 \%$ \\
\hline Yes, definitely & 0 & $0 \%$ \\
\hline
\end{tabular}

Source: Author's own elaboration based on research results.

As plotted in the table, over half of the respondents never used nomenclature incomprehensible for students, whereas a total of $43 \%$ happened to do that. The reason behind it may be found in self-enhancement needs that underpin self-construction. Generally, most people want to think of themselves as competent, eloquent etc. Thus, by convincing others that they are experts in a particular fields, people are more likely to convince themselves. Furthermore, the willingness to self-present is inclined to increase when other people's attention is called to us. Certain stimuli may also make us aware of how we are perceived, on the grounds that they remind us of how we are seen by others ${ }^{24}$. Using nomenclature that the students are not familiar with knowingly may also result in boasting or showing off, which is one of the main risks of this strategy.

\subsection{The strategy of exemplification}

With the strategy of exemplification, it is attempted to create the impression that someone is morally superior, virtuous, or righteous. The second part of the research encompassed 5 questions connected to this strategy.

${ }^{23}$ B.R. Schlenker, Self-presentation: Managing the impression of consistency when reality interferes with self-enhancement, "Journal of Personality and Social Psychology", Washington 1975, p. 1030-1037.

${ }^{24}$ C.S. Carver, M.F Scheier, Aspects of self, and the control of behavior [in:] The self and social life, ed. B.R. Schlenker, New York 1985. 
Question 6 Have you ever told your students that it is inappropriate to say or do something?

Table 7. Distribution of answers to Question 6

\begin{tabular}{|l|c|c|}
\hline \multicolumn{1}{|c|}{ Answer } & Number of respondents & Percentage \\
\hline No, definitely not & 4 & $4 \%$ \\
\hline No & 9 & $9 \%$ \\
\hline Rarely (almost never) & 67 & $67 \%$ \\
\hline Yes & 15 & $15 \%$ \\
\hline Yes, quite frequently & 5 & $5 \%$ \\
\hline Yes, definitely & 0 & $0 \%$ \\
\hline
\end{tabular}

Source: Author's own elaboration based on research results.

As tabulated, $67 \%$ of the respondents were rather tentative and the case when they told their students about the inappropriateness of some actions occurred rather infrequently. However, the total of $20 \%$ of the academic teachers appeared to have said that explicitly. $13 \%$ of the respondents never decided to have tackled the issue of appropriateness. A situation when an academic teacher talks about inappropriateness, usually results from their dissatisfaction pertinent to students' actions or general performance. The rationale behind that may be found in self-construction, i.e. the willingness to construct a certain identity for ourselves. Frequently, self-construction may also be applied by an academic teacher to confirm a self-view that has already been established, such as acting only in accordance with the rules. Swann ${ }^{25}$ refers to this form of self-construction as self-verification, whereas Wicklund and Gollwitzer ${ }^{26}$ categorize such behaviour as self-symbolizing.

On the other hand, saying that doing something is appropriate or not, may create an opposite image, especially in the minds of students who do not support the same view.

Question 7 Have you ever deliberately made your students feel guilty?

Table 8. Distribution of answers to Question 7

\begin{tabular}{|l|c|c|}
\hline \multicolumn{1}{|c|}{ Answer } & Number of respondents & Percentage \\
\hline No, definitely not & 3 & $3 \%$ \\
\hline No & 28 & $28 \%$ \\
\hline Rarely (almost never) & 59 & $59 \%$ \\
\hline Yes & 3 & $3 \%$ \\
\hline Yes, quite frequently & 7 & $7 \%$ \\
\hline Yes, definitely & 0 & $0 \%$ \\
\hline
\end{tabular}

Source: Author's own elaboration based on research results.

25 W.B. Swann, To be adored or to be known? The interplay of self-enhancement and self-verification [in:] Motivation and cognition, eds. R.M. Sorrentino, E.T. Higgins, New York 1990, p. 408-448.

${ }^{26}$ R.A. Wicklund, P.M. Gollwitzer, Symbolic self-completion, New York 1982. 
Visibly enough, $59 \%$ of the respondents happened to make their students feel guilty, whereas $10 \%$ in total explicitly admitted doing that. $31 \%$ of academic teachers never evoked guilt in their students. Academic teachers, who happen to trigger guilt in their students may, deliberately or not, use it as a form of some psychological manipulation to punish them for something they should not have done. Eliciting guilt on a daily basis may be conducive to developing in students a performance goal-orientation rather than the one focused on learning, which in turn may make students anxious about getting an unfavourable judgement of their competence. In consonance with that, avoiding unfavourable judgements creates a perception that every task is a test of their abilities, ergo a potential opportunity to fail. Contrary to that, if students focus more on the learning goal-orientation, they acquire new skills, attempt to understand something they are not familiar with, apply adaptive learning strategies, and do not have difficulty seeking help while encountering obstacles.

The dichotomy of learning and performance goals stems from research conducted by Ames\&Archer ${ }^{27}$, Dweck ${ }^{28}$, and Dweck\&Leggett ${ }^{29}$, yet, visibly enough, many motivation theorists have recently supported the view that students' performance may be enhanced by creating a learning environment that enables students to achieve learning goals in lieu of performance-related ones. In contrast with that, as pondered by Tangney and Dearing ${ }^{30}$ inasmuch as students need to be held responsible for what they did, it is the behaviour that should be accentuated, not the person. It is prudent to eschew ridiculing or announcing student's guilt publicly to control their behaviour. In preference to that, an academic teacher ought to allow for natural consequences.

\section{Question 8 Have you ever told your students that presently people lack morals?}

Table 9. Distribution of answers to Question 8

\begin{tabular}{|l|c|c|}
\hline \multicolumn{1}{|c|}{ Answer } & Number of respondents & Percentage \\
\hline No, definitely not & 29 & $29 \%$ \\
\hline No & 38 & $38 \%$ \\
\hline Rarely (almost never) & 33 & $33 \%$ \\
\hline Yes & 0 & $0 \%$ \\
\hline Yes, quite frequently & 0 & $0 \%$ \\
\hline Yes, definitely & 0 & $0 \%$ \\
\hline
\end{tabular}

Source: Author's own elaboration based on research results.

Explicitly, none of the surveyed academic teachers claimed to have told their students that presently people lack morals. $33 \%$ were tentative in their judgements, whereas over

${ }^{27}$ C. Ames, J. Archer, Achievement goals in the classroom: Students' learning strategies and motivation processes, "Journal of Educational Psychology", Vol. 80/3, Illinois 1988, p. 260-267.

${ }^{28}$ C. Dweck, Motivational processes affecting learning [in:] American Psychologist, Washington, 1986, p. 1040-1048.

${ }^{29}$ C. Dweck, E. Leggett, A social-cognitive approach to motivation and personality, "Psychological Review", Vol. 95, Washington 1988, p. 256-273.

30 J.P. Tangney, R.L. Dearing, Shame and guilt, New York 2002. 
$60 \%$ never did that. Basically, if a person states that others lack something it is indicative that this person has it, or at least assumes so. The teacher's role is the one of a guide, and there are assorted reasons for role internalization to occur.

According to the reflected appraisal process ${ }^{31}$, people perceive themselves the way they believe other people perceive them, ergo social interaction is a vital factor in developing self-conceptions. Contrary to that, recent studies enable to draw different inferences. People are rather unlikely to see clearly how they are perceived by others, especially strangers. Instead, they believe that other people see them the way they see themselves ${ }^{32}$. As formulated by Thagard and Wood ${ }^{33}$ 'instead of others' views influencing one's self-view, then, one's self-view determines how one thinks others view oneself. It is possible, however, that within close relationships, the reflected self plays a greater role in shaping the self-concept'. Here, the teacher stating that other people lack morals plays the role of the morally superior and the one who discriminates between what is right or wrong.

This is inextricably linked to the afore-postulated view that the teacher may assume that the students share the self-perception. Unfortunately, playing the 'morally superior', while judging other people's actions may lead to being perceived as sanctimonious.

Question 9 Have you ever told your students that you would not finish the classes earlier, because it is against the rules?

Table 10. Distribution of answers to Question 9

\begin{tabular}{|l|c|c|}
\hline \multicolumn{1}{|c|}{ Answer } & Number of respondents & Percentage \\
\hline No, definitely not & 0 & $0 \%$ \\
\hline No & 29 & $29 \%$ \\
\hline Rarely (almost never) & 48 & $48 \%$ \\
\hline Yes & 19 & $19 \%$ \\
\hline Yes, quite frequently & 4 & $4 \%$ \\
\hline Yes, definitely & 0 & $0 \%$ \\
\hline
\end{tabular}

Source: Author's own elaboration based on research results.

As plotted in the table, the total of $71 \%$ of the academic teachers happened not to finish the classes earlier considering it as acting against the rules, whereas $29 \%$ of the respondents did not use it as a reason. Again, the motivation behind that may be found in self-construction, for it confirms an already established self-view such as acting only in accordance with the rules (See Question 6 for comparison).

${ }^{31}$ G.H. Mead, Mind self, and society, Chicago: University of Chicago Press 1934.

32 D.M. Tice, H.M. Wallace, The reflected self: creating yourself as (you think) others see you [in:] Handbook of Self and Identity, eds. M.R. Leary and J.P. Tangney, New York, NY: Guilford Press, 2003, p. 91-105.

${ }^{33}$ P. Thagard, J.V. Wood, Eighty phenomena about the self: Representation, evaluation, regulation, and change, "Frontiers in Psychology", Vol. 6, Seattle 2015. 
Question 10 Have you ever told your students that you find it difficult to understand modern youth?

Table 11. Distribution of answers to Question 10

\begin{tabular}{|l|c|c|}
\hline \multicolumn{1}{|c|}{ Answer } & Number of respondents & Percentage \\
\hline No, definitely not & 42 & $42 \%$ \\
\hline No & 41 & $41 \%$ \\
\hline Rarely (almost never) & 17 & $17 \%$ \\
\hline Yes & 0 & $0 \%$ \\
\hline Yes, quite frequently & 0 & $0 \%$ \\
\hline Yes, definitely & 0 & $0 \%$ \\
\hline
\end{tabular}

Source: Author's own elaboration based on research results.

Conspicuously, none of the surveyed academic teachers claimed explicitly to have told their students that it is difficult to understand modern youth. $17 \%$ were tentative in their judgements, whereas a total of $83 \%$ never did that. Telling students that understanding their generation is difficult along with pretending to be superior and morally upright may result in creating unnecessary distance. A situation when an academic teacher is prone to conclude in this way, usually ensues from their dissatisfaction as regards students' performance or actions in general. That may be associated with the notion of role internalization. Notwithstanding, the inclination to define oneself against the backdrop of one's social roles, does not constitute merely the link between social roles and self-conceptions. Every social role encompasses a set of behavioural expectations and assumptions concerning one's personal characteristics.

In the course of playing social roles, people often come to internalize role-relevant personal characteristics. They come to see themselves as possessing the qualities suggested by the roles they play. Again, lack of teacher's understanding of students' generation indicates potential wrongness in their actions, whereas the teacher playing the 'teaching role' is the one who guides, and discriminates between what is right or wrong.

\section{CONCLUSION}

The paper investigated the application of self-presentation strategies in academic surroundings, and juxtaposes them with their potential impact on students. The strategy of selfpromotion is helpful while people endeavour to draw attention to their attainments in order to be regarded as competent or capable. Most importantly, though seemingly akin to ingratiation, the strategy of self-promotion does not focus on building a likable image. One of potential risks pertinent to inapt use of this strategy is appearing as conceited and fraudulent. The second strategy, exemplification, creates the impression that someone is morally superior, virtuous, or righteous, yet sometimes at the expense of being viewed as hypocritical, sanctimonious, or selfish.

Based on the online questionnaire completed by 100 academic teachers, it may be inferred that the strategies of self-promotion and exemplification were the least frequently chosen ones. The rationale behind this result may be found in teacher's reluctance to appear 
as showing off or being vainglorious. As already stated, people, including teachers, aim at relatedness, i.e. they want to belong to groups of people that they care for, here - the students. Essentially, people are aware that it is more probable to successfully integrate with those who perceive them positively. To this end, they frequently endeavour to establish a favourable impression.

Most conspicuously, individual's public behaviour determines to some extent private self-conceptions. People are audiences for their own behaviour. Inasmuch as our behaviour may convince other people that we are competent or able, we may, too, convince ourselves.

To conclude it is prudent to adduce Park's wording: 'everyone is always and everywhere, more or less consciously, playing a role. It is in these roles that we know each other; it is in these roles that we know ourselves' ${ }^{34}$. The main limit of the research connected to the Likert scale proved wrong, on the grounds that teachers were not inclined to choose answers right in the middle of the questionnaire, nor afraid to state their opinions clearly. The paper may well constitute a basis for further research on self-presentation strategies applied in academic surroundings. It is also worth scrutinizing, what personal traits - if any - may determine the inclination to behave in certain ways.

\section{REFERENCES}

1. Akerlof G.A, Kranton R.E., Economics and Identity, "The Quarterly Journal of Economics", Vol. 115/3, Oxford, 2000.

2. Akerlof G.A., Kranton R.E., Identity Economics: How Our Identities Shape Our Work, Wages and Well-Being, Princeton University Press 2010.

3. Ames C., Classrooms: Goals, structures, and student motivation, “ Journal of Educational Psychology", Vol. 84, University of Illinois Press, Illinois 1992.

4. Ames C., Archer J., Achievement goals in the classroom: Students' learning strategies and motivation processes, "Journal of Educational Psychology", Vol. 80/3, Illinois 1988.

5. Arkin R.M., Baumgardner A.H., Self-handicapping [in:] Basic issues in attribution theory and research, eds. J.H. Harvey and G. Weary, Academic Press, New York 1985.

6. Baumeister R.F., A self-presentational view of social phenomena, "Psychological Bulletin", Vol. 91, Washington 1982.

7. Baumeister R.F., Tice D.M., Hutton D.G., Self-presentational motivations and personality differences in self-esteem, "Journal of Personality", Vol. 57, John Wiley \& Sons, Inc., 1989.

8. Baumeister R.F., Leary M.R., The need to belong: desire for interpersonal attachments as a fundamental human motivation, "Psychological Bulletin", 117, Washington 1995.

9. Baumeister R.F., The self [in:] The Handbook of Social Psychology, eds. D.T. Gilbert, S.T. Fiske, G. Lindzey, New York 1998.

10. Bénabou R., Tirole J., Intrinsic and Extrinsic Motivation, "The Review of Economic Studies", Vol. 70/3, London 2003.

11. Bénabou R., Tirole J., Incentives and Prosocial Behavior, “American Economic Review”, Vol. 96/5, American Economic Association 2006.

\footnotetext{
${ }^{34}$ R.E. Park, Human nature and collective behavior, "American Journal of Sociology", Vol. 32, Chi-
} cago 1927, p. 733-741. 
12. Bursztyn L., Jensen R., Social Image and Economic Behavior in the Field: Identifying, Understanding, and Shaping Social Pressure, "Annual Review of Economics", Vol. 9/1, Palo Alto, USA 2017.

13. Carver C.S., Scheier M.F, Aspects of self, and the control of behavior [in:] The self and social life, ed. B.R. Schlenker, New York 1985.

14. Deci E.L., Ryan R.M., The "what" and "why" of goal pursuits: human needs and the selfdetermination of behaviour, "Psychological Inquiry", Vol. 11, London, 2000.

15. Dweck C., Motivational processes affecting learning, "American Psychologist", Washington, 1986.

16. Dweck C., Leggett E., A social-cognitive approach to motivation and personality, "Psychological Review", Vol. 95, Washington 1988.

17. Goffman E., The presentation of self in everyday life, Doubleday, New York 1959.

18. Jones E.E., Pittman T.S., Toward a general theory of strategic self-presentation [in:] Psychological perspectives on the self, ed. J. Suls, New York 1982.

19. Jones E.E., Interpersonal perception, W.H. Freeman and Co, New York 1990.

20. Leary M.R., Kowalski R.M., Impression management: A literature review and two-component model, "Psychological Bulletin", Washington 1990.

21. Maehr M., Midgley C., Enhancing student motivation: A school-wide approach [in:] Educational Psychologist, London 1991.

22. McCall G.J., Identities and interactions, The Free Press, New York 1966.

23. Mead G.H., Mind self, and society, University of Chicago Press, Chicago 1934.

24. Montalvo G.P., Pleasing the teacher: A student perspective, Unpublished manuscript, 1995.

25. Montalvo G.P., Roedel T., Pleasing the teacher: A qualitative look, Paper presented at the annual meeting of the American Educational Research Association, San Francisco 1995.

26. Newman R., What do I need to do to succeed when I don't understand what I'm doing: Developmental influences on student adaptive help seeking [in:] Development of Achievement Motivation, eds. A. Wigfield and S. Eccles, San Diego, CA: Academic Press 2002.

27. Park R.E., Human nature and collective behavior, "American Journal of Sociology", Vol. 32, Chicago 1927.

28. Rosenberg M., Conceiving the self, Basic Books, New York 1979.

29. Sarbin T.R., Allen V.L., Role theory [in:] The handbook of social psychology, eds. G. Lindzey, E. Aronson, Reading, MA: Addison-Wesley 1968.

30. Schlenker B.R., Self-presentation: Managing the impression of consistency when reality interferes with self-enhancement, "Journal of Personality and Social Psychology", Washington 1975.

31. Scheier M.F., Carver C.S., Two sides of the self: One for you and one for me [in:] Psychological perspectives on the self, eds. J. Suls, A.G., Greenwald. Hillsdale, NJ: Lawrence Erlbaum Associates 1982.

32. Schlenker B.R., Impression management: The self-concept, social identity, and interpersonal relationships, Monterey, CA: Brooks/Cole 1980.

33. Schlenker B.R., Leary M.R., Audiences' reactions to self-enhancing, self-denigrating, and accurate self-presentations, "Journal of Experimental Social Psychology", Washington 1982.

34. Schlenker B.R., Identity and self-identification [in:] The self and social life, ed. B.R. Schlenker, McGraw-Hill, New York 1985. 
35. Schlenker B.R, Weigold M.F., Goals and the self-identification process: Constructing desired identities [in:] Goal concepts in personality and social psychology, ed. L.A. Pervin, Hillsdale, NJ: Erlbaum 1989.

36. Schlenker B.R., Trudeau J.V., The impact of self-presentations on private self-beliefs: Effects of prior self-beliefs and misattribution, "Journal of Personality and Social Psychology", Washington 1990.

37. Schlenker B.R., Self-presentation [in:] Handbook of Self and Identity, eds. M.R. Leary and J.P. Tangney, New York 2003.

38. Schneider D.J., Tactical self-presentations: Toward a broader conception [in:] Impression management theory and social psychological research, ed. J.T. Tedeschi, New York 1981.

39. Stryker S., Statham A., Symbolic interaction and role theory [in:] The handbook of social psychology, eds. G. Lindzey, E. Aronson, Random House, New York 1985.

40. Swann W.B., To be adored or to be known? The interplay of self-enhancement and selfverification [in:] Motivation and cognition, eds. R.M. Sorrentino, E.T. Higgins, New York 1990.

41. Tangney J.P., Dearing R.L., Shame and guilt, New York 2002.

42. Tedeschi J. T., Private and public experiences and the self [in:] Public self and private life, ed. R.F. Baumeister, Springer-Verlag, New York 1986.

43. Thagard P., Wood J.V., Eighty phenomena about the self: Representation, evaluation, regulation, and change, "Frontiers in Psychology", Vol. 6, Seattle 2015.

44. Tice D.M., Butler J.L., Muraven M.B., Stillwell A.M, When modesty prevails: differential favorability of self-presentation to friends and strangers, "Journal of Personality and Social Psychology", Washington 1995.

45. Tice D.M., Wallace H.M., The reflected self: creating yourself as (you think) others see you [in:] Handbook of Self and Identity, eds. M.R. Leary and J.P. Tangney, New York 2003.

46. Wicklund R.A., Gollwitzer P.M., Symbolic self-completion, New York 1982.

\section{STRATEGIE AUTOPREZENTACJI STOSOWANE PRZEZ RZESZOWSKICH WYKŁADOWCÓW I ICH POTENCJALNY WPŁYW NA STUDENTÓW - AUTOPROMOCJA I EGZEMPLIFIKACJA}

Artykuł podejmuje problematykę zastosowania strategii autoprezentacji w warunkach akademickich i zestawia je $\mathrm{z}$ ich potencjalnym wpływem na studentów. Dane przedstawione $\mathrm{w}$ artykule zostały wyekscerpowane z badań przeprowadzonych w lutym i marcu 2018 roku, odnośnie do zastosowania przez rzeszowskich wykładowców strategii ingracjacji, intymidacji, autopromocji, suplikacji i egzemplifikacji. Autoprezentacja to, w uproszczonych słowach, dobór zachowań mających na celu zarządzanie własnym wizerunkiem i tym jak postrzegają nas inni, podczas gdy strategia autoprezentacji to dobór środków do budowania konkretnego obrazu. Artykuł obejmuje grupę 100 rzeszowskich wykładowców akademickich, mężczyzn i kobiet, pomiędzy 26. i 62. rokiem życia. Badania przeprowadzone za pośrednictwem ankiety online wykazały, że autopromocja i egzemplifikacja były najrzadziej wybieranymi strategiami. Każda ze strategii objęła pięć powiązanych tematycznie pytań. Wynik ten może wynikać z faktu, że wykładowcy nie chcą być postrzegani jako próżni, lub zapatrzeni w siebie. Podczas konstruowania pytań autorka starała się dopasować je tematycznie do danej strategii 
na tyle na ile to możliwe. Cechy charakterystyczne każdej z dwóch strategii zostały wyodrębnione podczas budowania kognitywnej rzeczywistości wokół pytania.

Słowa kluczowe: autoprezentacja, strategia, autopromocja, egzemplifikacja, nauczyciel akademicki.

DOI: $10.7862 / \mathrm{rz} .2018 . \mathrm{mmr} .14$

Tekst złożono $w$ redakcji: maj $2018 \mathrm{r}$.

Przyjęto do druku: czerwiec 2018 r. 
